\title{
Lactococcus lactis contains only one glutamate decarboxylase gene
}

\author{
Masaru Nomura, ${ }^{1}$ Ikuyo Nakajima, ${ }^{1}$ Yasuhito Fujita, ${ }^{1}$ Miho Kobayashi, ${ }^{1}$ \\ Hiromi Kimoto, ${ }^{1}$ Ichirou Suzuki ${ }^{1}$ and Hisashi Aso ${ }^{2}$
}

Department of Animal Products ${ }^{1}$ and Department of Animal Physiology². National Institute of Animal Industry, Norindanchi, Tsukuba, Ibaraki 305-0901, Japan

\author{
Author for correspondence: Masaru Nomura. Tel: +8129838 8688. Fax: +81 298388688 . \\ e-mail: nomura@niai.affrc.go.jp
}

\begin{abstract}
Glutamate decarboxylase, which is associated with a glutamate-dependent acid-resistance mechanism, was purified from Lactococcus lactis subsp. lactis by a three-step procedure. The specific activity was increased about 114-fold with a yield of $16 \%$. The $N$-terminal amino acid sequence of the enzyme was determined. The gene encoding this enzyme was cloned in Escherichia coli, and its nucleotide sequence was determined. The deduced amino acid sequence suggests that the enzyme is produced as a mature form (466 amino acid residues), not as a precursor protein. The subunit molecular mass of $L$. lactis glutamate decarboxylase was calculated to be $53926 \mathrm{Da}$. The enzyme was maximally active at pH 4.7 and reacted only with L-glutamate among 20 $\alpha$-amino acids. The apparent $K_{m}$ value was calculated to be $0.51 \mathrm{mM}$. The activity was stable at acidic pH values; there was no activity in the neutral pH range. At pH 4.1 the enzyme activity was retained at temperatures up to $70{ }^{\circ} \mathrm{C}$ in $\mathbf{1 0} \mathrm{min}$ incubations. L. lactis glutamate decarboxylase behaved as a single protein when the enzyme was purified. A single band corresponding to the glutamate decarboxylase gene was detected on Southern blot analysis. These data suggest that there is one glutamate decarboxylase gene in $L$. lactis.
\end{abstract}

Keywords: Lactococcus lactis, glutamate decarboxylase, acid resistance, gadB

\section{INTRODUCTION}

Glutamate decarboxylase (GAD; EC 4.1.1.15) catalyses the irreversible decarboxylation of L-glutamate to GABA. GAD has been isolated from a wide variety of sources and its biochemical properties have been characterized. Escherichia coli GAD (Fonda, 1985) is a homohexameric enzyme with a subunit size of $50 \mathrm{kDa}$. Each subunit contains a pyridoxal phosphate bound to a lysyl residue. E. coli contains two copies of GAD structural genes that map to different positions on the chromosome (Smith et al., 1992). They are $98 \%$ similar at the nucleotide level. Induction of GAD is one of the acid stress responses in bacteria (Bearson et al., 1997).

Lactococcus lactis is a Gram-positive coccus that forms pairs or chains and produces L-lactate from glucose.

Abbreviations: GABA, $\gamma$-aminobutyric acid; GAD, glutamate decarboxylase; CBB, Coomassie brilliant blue; $\mathrm{PGI}$, phosphoglucose isomerase.

The DDBJ accession number for the sequence reported in this paper is AB010789.
Lactococcal strains are essential to milk fermentation, especially in the cheese-making process, to provide optimal conditions for curd formation and for the development of texture and flavour. Since L. lactis increases the acidity through its anaerobic fermentation, it is likely to have acid-resistance mechanisms to maintain viability under low-pH conditions. Amino acid decarboxylation decreases the acidity by the consumption of hydrogen ions. The generation of carbon dioxide by glutamate decarboxylation can cause cheeseeye formation during cheese ripening (Zoon \& Allersma, 1996).

Sanders et al. (1998) sequenced the L. lactis gadCB gene and suggested that it encoded a glutamate-dependent acid-resistance mechanism comprised of glutamateGABA antiporter and GAD. As it is difficult to purify GAD protein, the biochemical characteristics of the $L$. lactis enzyme have not yet been elucidated. In this study, we purified $L$. lactis GAD 114-fold by a three-step procedure and investigated its biochemical characteristics. Additional experiments indicated that there was only one GAD structural gene in L. lactis. 


\section{METHODS}

Materials. An M3A-Sepharose column (Nomura et al., 1997) was used for the purification of L. lactis GAD. The monoclonal antibody (mAb) M3A is specific to L. lactis phosphoglucose isomerase (PGI). The mAb was bound to EAH-Sepharose 4B (Pharmacia) by carbodiimide coupling.

Bacterial strains and growth conditions. Lactococcus lactis subsp. lactis biovar diacetylactis 01-7 was isolated from a cheese starter (Nomura et al., 1998). L. lactis was maintained in sterile litmus milk and subcultured once a week. TYG medium ( $\mathrm{pH} 6.8$ ) consisted of $0.5 \%$ tryptone (Difco), $0.5 \%$ yeast extract (Difco), $1 \%$ glucose and $0.5 \%$ sodium succinate. An actively growing culture was obtained by transferring $1 \%$ inoculum to TYG medium and incubated at $30^{\circ} \mathrm{C}$ for $16 \mathrm{~h}$. Escherichia coli XL-1 Blue (Stratagene), used as the cloning host, was grown in LB medium. For screening of recombinants, LB medium was supplemented with ampicillin $(50 \mu \mathrm{g}$ $\left.\mathrm{ml}^{-1}\right)$, X-Gal $\left(100 \mu \mathrm{g} \mathrm{ml}^{-1}\right)$ and IPTG $(0.5 \mathrm{mM})$.

Purification of GAD activity. All steps were done at $4{ }^{\circ} \mathrm{C}$. Actively growing culture of $L$. lactis $01-7(20 \mathrm{ml})$ was transferred to 2 litres of TYG medium. After incubation for $14 \mathrm{~h}$ at $30^{\circ} \mathrm{C}$, cells were harvested by centrifugation at $1800 \mathrm{~g}$ for $20 \mathrm{~min}$. Pellets were washed once with $20 \mathrm{mM}$ sodium phosphate buffer ( $\mathrm{pH} 7 \cdot 2$ ) and resuspended with $100 \mathrm{ml}$ of the same buffer containing lysozyme $\left(0.1 \mathrm{mg} \mathrm{ml}^{-1}\right.$, Wako Pure Chemicals), $N$-acetylmuramidase $\left(0.1 \mu \mathrm{g} \mathrm{ml} \mathrm{m}^{-1}\right.$ Seikagakukogyo) and DNase I (4 $\mathrm{U} \mathrm{ml}^{-1}$, Takara Shuzo). After $2 \mathrm{~h}$ incubation at $37^{\circ} \mathrm{C}$, the cell suspension was sonicated using a Tomy UR-150P ultrasonic cell breaker for $5 \mathrm{~min}$. Cell debris was removed by centrifugation at $11000 \mathrm{~g}$ for $10 \mathrm{~min}$. Ammonium sulfate was added to the cell-free extract to give a final concentration that was $80 \%$ saturated. After $2 \mathrm{~h}$ incubation, the precipitates were collected by centrifugation at $8000 \mathrm{~g}$ for $20 \mathrm{~min}$ and redissolved with PBS $(10 \mathrm{mM}$ sodium phosphate buffer containing $0.15 \mathrm{M} \mathrm{NaCl}, \mathrm{pH} 7 \cdot 4)$. The supernatant was collected by centrifugation at $11000 \mathrm{~g}$ for $10 \mathrm{~min}$, applied to a Sephacryl S-300 column $(4 \times 80 \mathrm{~cm})$ and the column developed with PBS. Active fractions were pooled and loaded onto an M3A-Sepharose column ( $2 \mathrm{ml}$ ) which had been equilibrated with PBS. The column was washed with PBS and eluted by a stepwise gradient of the following $\mathrm{NaCl}$ concentrations in PBS (10 ml each): 0.20, 0.25, 0.30,0.35 and $0.40 \mathrm{M}$. The active fraction was dialysed against $50 \mathrm{mM}$ sodium acetate buffer $(\mathrm{pH} 4.6)$ and stored at $-20^{\circ} \mathrm{C}$ until use. The experiments were done several times; results of a typical example are given.

Protein concentration was determined by the BCA protein assay reagent (Pierce).

Electrophoresis. SDS-PAGE on a $10 \%$ polyacrylamide gel was carried out under reducing conditions as described by Laemmli (1970). Native PAGE was performed using the standard pore formation of Davis at $\mathrm{pH} 7.5$ (Gabriel, 1971). After electrophoresis, gels were stained with $0 \cdot 1 \%$ Coomassie brilliant blue R-250 (CBB) and destained with $30 \%$ methanol.

GAD assay. GAD activity was measured as described previously (Nomura et al., 1998). The reaction mixture consisted of $1 \mathrm{ml} 50 \mathrm{mM}$ sodium acetate buffer $\mathrm{pH} 4.7$ containing $2 \mathrm{mM}$ L-glutamate, $0.1 \mathrm{mM}$ pyridoxal phosphate and aliquots of the enzyme preparation. The amount of GABA produced was determined using a Hitachi L-8500 amino acid analyser. One unit of GAD was defined as the amount of enzyme required to produce $1 \mu \mathrm{mol} \mathrm{GABA}$ from L-glutamate per min at $30^{\circ} \mathrm{C}$ and $\mathrm{pH} 4 \cdot 7$.
$\mathbf{N}$-terminal amino acid sequencing. GAD protein $(5 \mu \mathrm{g})$ was separated on a $10 \%$ SDS-PAGE gel and electrotransferred to a PVDF membrane. The membrane was stained with $0 \cdot 1 \%$ CBB, destained with $60 \%$ methanol, washed in distilled water and dried. The GAD band was cut out and was subjected to micro-sequencing on a Beckman LF-3400 gas-phase sequencer.

DNA methods. Unless specified otherwise, all manipulations of DNA were performed as described by Sambrook et al. (1989). Plasmid DNA from E. coli was isolated by the alkaline lysis method (Sambrook et al., 1989). Genomic DNA from $L$. lactis was isolated by the method of Saito \& Miura (1963); plasmid DNA from $L$. lactis was isolated according to Anderson \& McKay (1983). pBluescript II SK ( - ) (Stratagene) was used as the cloning vector. Southern blots were transferred to Hybond-N (Amersham) and hybridized with probes that were labelled with digoxigenin-dideoxyUTP using a DIG DNA labelling and detection kit (Boehringer). Hybridization was performed at $42{ }^{\circ} \mathrm{C}$ in a buffer containing $50 \%$ formamide. The filter was washed twice in $2 \times \mathrm{SSC} / 0.1 \%$ SDS at room temperature and then twice in the same buffer at $68^{\circ} \mathrm{C}$.

DNA sequence analysis. DNA fragments inserted into the polylinker of pBluescript II were deleted unidirectionally by using a kilo-sequencing deletion kit (Takara Shuzo). Nested deletion clones were sequenced as described by Sanger et al. (1977) using a Taq dye-primer cycle sequencing kit and M13 universal dye primer (Applied Biosystems). Both strands were sequenced. Sequence data were assembled and analysed using the GENETYX Mac version 9.0.1 software (Software Development).

\section{RESULTS}

\section{Purification of GAD from $L$. lactis}

Purification of $L$. lactis GAD was first attempted with a procedure consisting of salting out, hydrophobic batch fractionation, gel filtration and anion-exchange chromatography. The purified GAD fraction, however, still manifested PGI activity. N-terminal amino acid

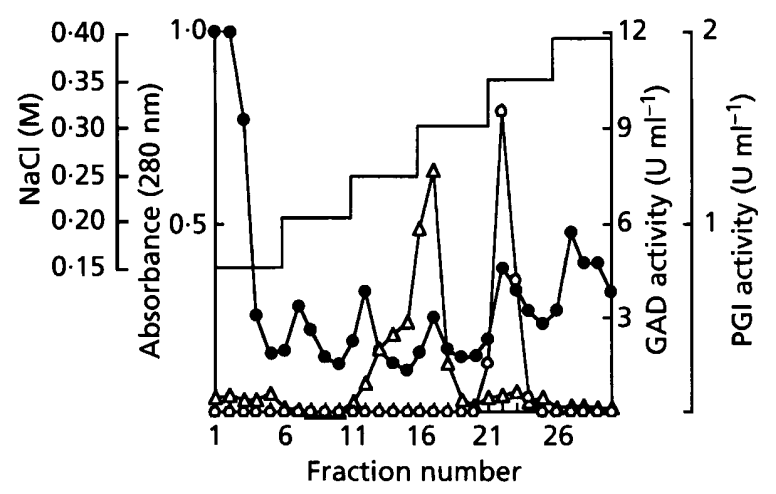

Fig. 1. MBA-Sepharose chromatography of $L$. lactis GAD. The partially purified GAD fraction $(6.8 \mathrm{mg}$ protein) was applied to the column $(2 \mathrm{ml})$ which had been equilibrated with PBS. The elution conditions and the detection of GAD were as described in Methods. PGI activity assay was as described previously (Nomura et al., 1997). Fractions of $2 \mathrm{ml}$ were collected. $\mathrm{NaCl}$ concentration;,$A_{280} ; O, G A D$ activity; $\triangle$, PGl activity. 
Table 1. Summary of GAD purification from $L$. lactis

\begin{tabular}{|lccccc|}
\hline Step & $\begin{array}{c}\text { Total activity } \\
(\mathbf{U})\end{array}$ & $\begin{array}{c}\text { Total protein } \\
(\mathbf{m g})\end{array}$ & $\begin{array}{c}\text { Specific activity } \\
\left(\mathbf{U ~ m g}^{-1}\right)\end{array}$ & $\begin{array}{c}\text { Yield } \\
(\%)\end{array}$ & $\begin{array}{c}\text { Purification } \\
\text { (-fold) }\end{array}$ \\
\hline Crude extract & 197 & 424 & 0.466 & 100 & 1 \\
Ammonium sulfate & 184 & 412 & 0.446 & 93 & 1 \\
Sephacryl S-300 & $47 \cdot 6$ & 6.84 & 6.96 & 24 & 15 \\
M3A-Sepharose & $31 \cdot 2$ & 0.584 & $53 \cdot 2$ & 16 & 114 \\
\hline
\end{tabular}

sequencing of this fraction indicated that a major protein of the fraction was L. lactis PGI rather than GAD. Therefore, a column with an anti-PGI mAb bound to Sepharose (M3A-Sepharose) was used for the purification of GAD. GAD activity, which was partially fractionated from the cell-free extract by salting out and subsequent gel filtration, was applied to the antibody column. Both GAD and PGI activities were adsorbed onto the column at a concentration of $0.15 \mathrm{M} \mathrm{NaCl}$ (Fig. 1). All of the GAD activity was eluted from the column as a single peak with an $\mathrm{NaCl}$ concentration of $0.35 \mathrm{M}$, whereas PGI activity was eluted at $0.30 \mathrm{M} \mathrm{NaCl}$. No PGI activity was detected in the GAD fraction. This indicated that GAD could be completely separated from PGI using an M3A-Sepharose column. It seemed that GAD adsorbed to the column better than PGI, although PGI was the original antigen for mAb M3A. As M3A had specific affinity for PGI in a Western blot analysis (Nomura et al., 1997), GAD may have a form similar to the epitope for $\mathrm{M} 3 \mathrm{~A}$ in its surface structure.

The purification of GAD from L. lactis 01-7 is summarized in Table 1 . The enzyme was purified so that it accounted for almost all the protein in the fraction. The specific activity of GAD was increased about 114-fold, with a yield of $16 \%$. The activity was observed as a single peak on both Sephacryl S-300 gel filtration and M3A-Sepharose chromatography. A GAD preparation from M3A-Sepharose chromatography was subjected to native PAGE to examine its purity. One major protein was observed, although a few minor contaminants were visible. GAD activity in slices of an unstained gel showed a single peak coinciding with a major band of the CBBstained gel. No other GAD activity was observed at the positions corresponding to any minor bands. PGI activity could not be detected in any slices of the gel. These data suggested that GAD activity of L. lactis resides in a single kind of protein. We used this fraction as the purified enzyme preparation for further studies.

\section{Properties of $L$. lactis GAD}

The $\mathrm{pH}$ dependence of GAD activity was examined. The activity was detected at $\mathrm{pH} 4 \cdot 0-5 \cdot 5$ and was maximal at $\mathrm{pH} 4 \cdot 7$. The enzyme reacted only with $\mathrm{L}-$ glutamate among the $20 \alpha$-amino acids (including proline) tested. The apparent $K_{\mathrm{m}}$ value calculated from a Lineweaver-Burk plot was $0.51 \mathrm{mM}$. The effect of $\mathrm{pH}$ on stability of the enzyme was examined at $30^{\circ} \mathrm{C}$ and $50^{\circ} \mathrm{C}$ for $5 \mathrm{~h}$ at various $\mathrm{pH}$ values. The enzyme was stable at acidic $\mathrm{pH}$ values ranging from 3.4 to 5.9 at $30{ }^{\circ} \mathrm{C}$ and to 4.6 at $50^{\circ} \mathrm{C}$. It showed no activity in the neutral $\mathrm{pH}$ range. The thermal stability of the enzyme was subsequently tested at $\mathrm{pH} 4.1$ for $10 \mathrm{~min}$. The activity remained at $90 \%$ or more from 30 to $70{ }^{\circ} \mathrm{C}$, but was rapidly lost at $80^{\circ} \mathrm{C}$. The purified enzyme preparation was subjected to an SDS-PAGE analysis. One major band was observed, suggesting that L. lactis GAD, like other bacterial GADs, consisted of identical subunits. The apparent molecular mass of the subunit was estimated to be about $54 \mathrm{kDa}$. Attempts to determine the native molecular mass of the L. lactis GAD by gel filtration gave unreliable results and were abandoned.

\section{$\mathbf{N}$-terminal amino acid sequence analysis}

The N-terminal amino acid sequence of the purified GAD was determined. Edman degradation provided a sequence of 15 residues from the N-terminus: MLYGKENRDEAEFLE. This agreed with the deduced amino acid sequence of the product of the gadB gene of L. lactis subsp. lactis MG1363 (Sanders et al., 1998). However, alignment of this sequence with those of the GADs of E. coli (Smith et al., 1992), Streptococcus pneumoniae (García \& López, 1995), cat (Kobayashi et al., 1987), drosophila (Jackson, 1990) and petunia (Baum et al., 1993) failed to find significant similarity. It was previously reported that the sequences of the $\mathrm{N}$-terminal region of various GADs were not similar, while the sequence of a 55-residue segment around the activecentre lysine was significantly conserved (Maras et al., 1992).

\section{DNA cloning and analysis}

The gene for the GAD of strain 01-7 was cloned from a partial HindIII library in pBluescript II SK $(-)$ by reverse genetics using a degenerate oligonucleotide $5^{\prime}$ TATGGAAAAGAAAATCGNGATGAA-3' designed on the $\mathrm{N}$-terminal amino acid sequence (residues 3 to 10). The $\mathrm{N}$-terminal sequences deduced from the open reading frame and determined from the purified enzyme were identical, and no prepro-sequence was observed. This indicated that the enzyme is produced as a mature form, not as a precursor protein. The sequence contained the active-site lysyl residue forming a Schiff base with pyridoxal phosphate and consensus amino acid residues conserved in GAD from mammalian and 
(a)

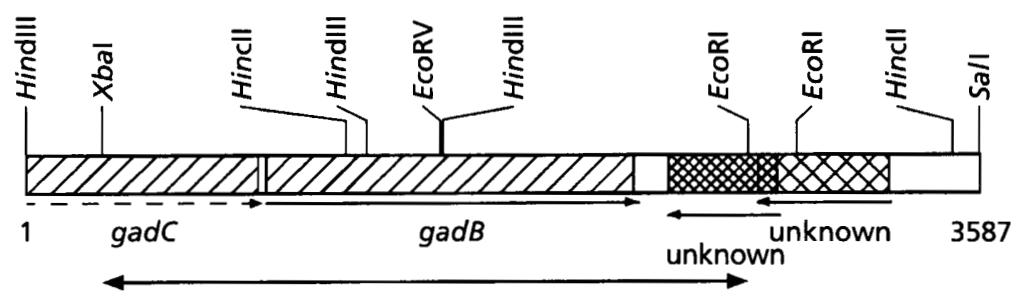

Hybridization probe

(b) 01-7 1:MLYGKENRDEAEFLEPIFGSESEQVDLPKYKLAQQSIEPRVAYQLVQDEMLDEGNARLNL 60

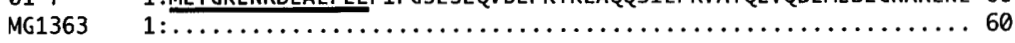

01-7 61:ATFCQTYMEPEAVKLMSQTLEKNAIDKSEYPRTTEIENRCVNMIADLWNASEKEKFMGTS 120

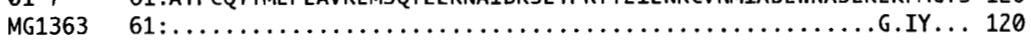

01-7 121:TIGSSEACML GGMAMKFSWRKRAEKLGLDINAKKPNLVISSGYQVCWEKFCIYWDIEMRE 180

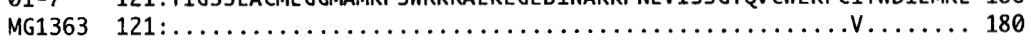

01-7 181:VPMDKEHMSINLDKVMDYVDEYTIGVVGIMGITYTGRYDDIKALDNLIEEYNKQTDYKVY 240 MG1363 181:...R...................................... 240

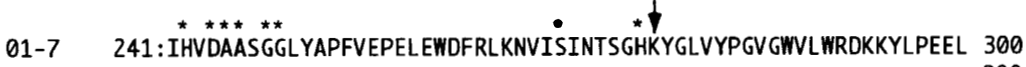

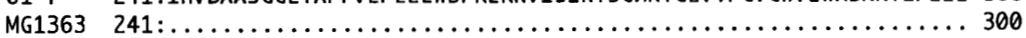

01-7 301:IFKVSYLGGELPTMAINFSHSASQLIGQYYNFVRYGFDGYKAIHERTHKVAMFLAKEIEK 360

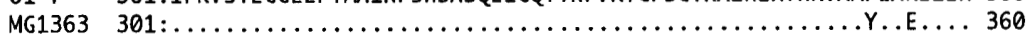

01-7 361:TGMFEIMNDGSQLPIVCYKLKEDSNRGWNLYDLADRLLMKGWQVPAYPLPKNLENEIIQR 420

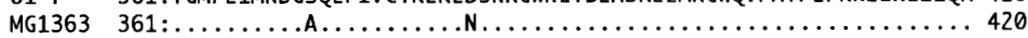

01-7 421:LVIRADFGMNMAFNYVQDMQEAIEALNKAHILYHEEPENKTYGFTH

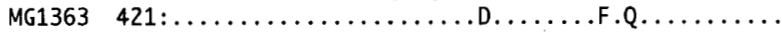

Fig. 2. Restriction map and deduced amino acid sequence of the gene for GAD of $L$. lactis strain 01-7. (a) Restriction map of the $3.6 \mathrm{~kb}$ Hindlil-Sall fragment of cloned 01-7 DNA. The dashed arrow indicates that gadC is incomplete. The hybridization probe for Southern blotting is shown by a long double-headed arrow below the map. (b) Primary structure alignment of GAD from $L$. lactis strains 01-7 and MG1363. A dot indicates a residue identical to both sequences. The sequence corresponding to the $\mathrm{N}$-terminal amino acid sequence of the purified enzyme is underlined. Residues conserved in GAD from many sources are marked by asterisks. The pyridoxalphosphate-binding lysine is arrowed. bacterial sources (Maras et al., 1992) (Fig. 2b). As expected, the gene and its deduced amino acid sequence were highly similar to $\mathrm{g} a d B$ and $\mathrm{GadB}$, respectively, of L. lactis MG1363 (Sanders et al., 1998). Seventy-six of 1398 bases were substituted. Fourteen of these affect the amino acid encoded, resulting in the substitutions of 13 residues of 466 amino acids.

\section{Southern blot analysis}

A $2.4 \mathrm{~kb} \mathrm{XbaI-EcoRI} \mathrm{fragment} \mathrm{was} \mathrm{labelled} \mathrm{and} \mathrm{used} \mathrm{as}$ a hybridization probe for the GAD gene (Fig. 2a). $L$. lactis 01-7 DNA was digested with restriction enzymes and subjected to Southern blotting (Fig. 3). One or two cross-hybridizing bands of sizes agreeing with expectations based on the restriction map were observed in all the digests. A single band was detected with the EcoRI, $X b a \mathrm{I}$ and EcoRI/XbaI digests, as the probe contained no sites for these enzymes. An EcoRV site was contained in the probe; two hybridizing bands were thus observed with this digest. Although the probe contained two internal HindIII sites, they were so near to each other that the probe did not hybridize efficiently to this small fragment under these conditions. These results indicated that there must be a single cross-hybridizing gene in $L$. lactis 01-7. Although strain 01-7 contained five or six plasmids, no hybridization signal was observed with these (data not shown), indicating that gadB is located on the chromosome. A Southern blot of another eight strains of $L$. lactis also suggested that gadB is a singlecopy gene (unpublished result).

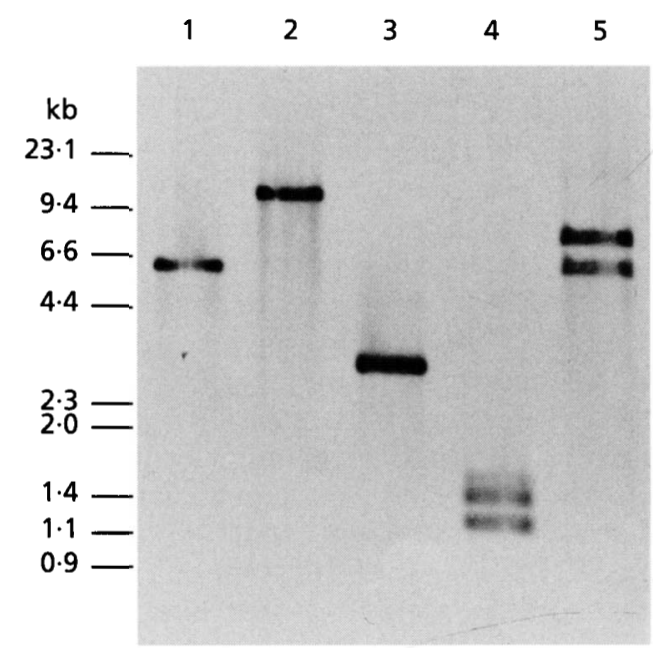

Fig. 3. Southern blot analysis of L. lactis subsp. lactis strain 01-7 DNA. The DNA was digested with EcoRI (lane 1), Xbal (lane 2), Xbal/EcoRI (lane 3), HindIII (lane 4) or EcoRV (lane 5). The blot was probed a digoxigenin-labelled $2.4 \mathrm{~kb}$ Xbal-EcoRI fragment (Fig. 2a).

\section{DISCUSSION}

In this study, we purified a protein with glutamate decarboxylation activity from $L$. lactis, demonstrated that this enzyme was GAD, and investigated its enzymic characteristics. The properties of $L$. lactis GAD were similar to those of E. coli GAD (Fonda, 1985). L. lactis 
GAD reacted only with L-glutamate at $\mathrm{pH} 4 \cdot 7$, with a $K_{\mathrm{m}}$ of $0.51 \mathrm{mM}$. It consisted of $54 \mathrm{kDa}$ subunits. The $E$. coli GAD also reacts only with L-glutamate at $\mathrm{pH} 4 \cdot 6$, with a $K_{\mathrm{m}}$ of $0.5-1.0 \mathrm{mM}$, and is composed of $50 \mathrm{kDa}$ subunits. This comparison suggests that $L$. lactis GAD is a typical bacterial GAD.

The role of bacterial amino acid decarboxylases has been proposed to be in the maintenance of acidic $\mathrm{pH}$ by the consumption of hydrogen ions as decarboxylation proceeds (Gale, 1946). Three amino-acid-dependent acid-resistance systems have been described for enterobacteria (Bearson et al., 1997). These systems involve the inducible amino acid decarboxylase, lysine decarboxylase, arginine decarboxylase and glutamate decarboxylase. When growth of L. lactis in skim milk stops, the cytoplasmic $\mathrm{pH}$ would be decreased to about pH 5.4-5.7 (Kashket, 1987; McDonald et al., 1990); subsequently acids diffuse into cells across the membrane, resulting in the lowering of the intracellular $\mathrm{pH}$ (Lee \& Wong, 1998). In this $\mathrm{pH}$ range GAD is able to decarboxylate the substrate better than lysine or arginine decarboxylases because their activities are optimal at pH 5.7-5.8 (Sabo et al., 1974; Soda \& Moriguchi, 1969) and $\mathrm{pH} 5 \cdot 2$ (Blethen et al., 1968), respectively. During milk fermentation L-glutamate, substrate for GAD, will be available in larger quantities than the other amino acids, because the milk protein casein contains a high proportion of glutamate. These facts suggest that GAD is likely to play a more significant role in acid resistance of $L$. lactis than the other amino acid decarboxylases.

Since $L$. lactis tolerates low $\mathrm{pH}$ conditions better than many other bacteria, it must contain effective acidresistance mechanisms. However, the present study indicated that $L$. lactis (a Gram-positive coccus) contains a single GAD gene ( $\operatorname{gadB}$ ), while the Gram-negative rods E. coli (Smith et al., 1992) and Shigella spp. (Small \& Waterman, 1998) contain two GAD genes. The functional properties of the two $E$. coli isozymes were identical (De Biase et al., 1996). Expression of these genes confers resistance to low $\mathrm{pH}$ (Waterman \& Small, 1996; Hersh et al., 1996; Sanders et al., 1998). As the properties of the enzymes were similar to each other, the function of the E. coli and L. lactis gadB genes seems likely to be similar. It is interesting that $L$. lactis shows the stronger acid-resistance phenotype, although it contains only one gadB gene.

\section{ACKNOWLEDGEMENTS}

The authors thank $T$. Okamoto for critically reading the manuscript.

\section{REFERENCES}

Anderson, D. G. \& McKay, L. L. (1983). Simple and rapid method for isolating large plasmid DNA from lactic streptococci. Appl Environ Microbiol 46, 549-552.

Baum, G., Chen, Y., Arazi, T., Takatsuji, H. \& Fromm, H. (1993). A plant glutamate decarboxylase containing a calmodulin binding domain. J Biol Chem 268, 19610-19617.
Bearson, S., Bearson, B. \& Foster, J. W. (1997). Acid stress responses in enterobacteria. FEMS Microbiol Lett 147, 173-180.

Blethen, S. L., Boeker, E. A. \& Snell, E. E. (1968). Arginine decarboxylase from Escherichia coli. J Biol Chem 243, 1671-1677.

De Biase, D., Tramonti, A., John, R. A. \& Bossa, F. (1996). Isolation, overexpression, and biochemical characterization of the two isoforms of glutamic acid decarboxylase from Escherichia coli. Protein Expr Purif 8, 430-438.

Fonda, M. L. (1985). L-Glutamate decarboxylase from bacteria. Methods Enzymol 113, 11-16.

Gabriel, O. (1971). Analytical disc gel electrophoresis. Methods Enzymol 22, 565-578.

Gale, E. F. (1946). The bacterial amino acid decarboxylases. $A d v$ Enzymol 6, 1-32.

García, E. \& López, R. (1995). Streptococcus pneumoniae type 3 encodes a protein highly similar to the human glutamate decarboxylase $\left(\mathrm{GAD}_{65}\right)$. FEMS Microbiol Lett 133, 113-118.

Hersh, B. M., Farooq, F. T., Barstad, D. N., Blankenhorn, D. L. \& Slonczewski, J. L. (1996). A glutamate-dependent acid resistance gene in Escherichia coli. J Bacteriol 178, 3978-3981.

Jackson, F. R. (1990). Prokaryotic and eukaryotic pyridoxaldependent decarboxylases are homologous. J Mol Evol 31, 325-329.

Kashket, E. R. (1987). Bioenergetics of lactic acid bacteria: cytoplasmic $\mathrm{pH}$ and osmotolerance. FEMS Microbiol Rev 46, 233-244.

Kobayashi, Y., Kaufman, D. L. \& Tobin, A. J. (1987). Glutamic acid decarboxylase cDNA. J Neurosci 7, 2768-2772.

Laemmli, U. K. (1970). Cleavage of structural proteins during the assembly of the head of bacteriophage T4. Nature 227, 680-685.

Lee, Y.-K. \& Wong, S.-F. (1998). Stability of lactic acid bacteria in fermented milk. In Lactic Acid Bacteria: Microbiology and Functional Aspects, 2nd edn, pp. 103-114. Edited by S. Salminen \& A. von Wright. New York: Marcel Dekker.

McDonald, L. C., Fleming, H. P. \& Hassan, H. M. (1990). Acid tolerance of Leuconostoc mesenteroides and Lactobacillus plantarum. Appl Environ Microbiol 56, 2120-2124.

Maras, B., Sweeney, G., Barra, D., Bossa, F. \& John, R. A. (1992). The amino acid sequence of glutamate decarboxylase from Escherichia coli. Eur J Biochem 204, 93-98.

Nomura, M., Nakajima, I., Matsuzaki, M., Kimoto, H., Suzuki, I. \& Aso, H. (1997). The N-terminal sequence of Lactococcus lactis phosphoglucose isomerase purified by affinity chromatography differs from the other species. Arch Biochem Biophys 341, 315-320.

Nomura, M., Kimoto, H., Someya, Y., Furukawa, S. \& Suzuki, I. (1998). Production of $\gamma$-aminobutyric acid by cheese starters during cheese ripening. J Dairy Sci 81, 1486-1491.

Sabo, D. L., Boeker, E. A., Byers, B., Waron, H. \& Fisher, E. H. (1974). Purification and physical properties of inducible Escherichia coli lysine decarboxylase. Biochemistry 13, 662-670.

Saito, H. \& Miura, K. (1963). Preparation of transforming deoxyribonucleic acid by phenol treatment. Biochim Biophys Acta 72, 619-629.

Sambrook, J., Fritsch, E. F. \& Maniatis, T. (1989). Molecular Cloning: a Laboratory Manual, 2nd edn. Cold Spring Harbor, NY: Cold Spring Harbor Laboratory.

Sanders, J. W., Leenhouts, K., Burghoorn, J., Brands, J. R., Venema, G. \& Kok, J. (1998). A chloride-inducible acid resistance mechanism in Lactococcus lactis and its regulation. Mol Microbiol 27, 299-310. 
Sanger, F., Nicklen, S. \& Coulson, A. R. (1977). DNA sequencing with chain-terminating inhibitors. Proc Natl Acad Sci USA 74, 5463-5467.

Small, P. L. C. \& Waterman, S. R. (1998). Acid stress, anaerobiosis and gadCB: lessons from Lactococcus lactis and Escherichia coli. Trends Microbiol 6, 214-216.

Smith, D. K., Kassam, T., Singh, B. \& Elliott, J. F. (1992). Escherichia coli has two homologous glutamate decarboxylase genes that map to distinct loci. J Bacteriol 174, 5820-5826.

Soda, K. \& Moriguchi, M. (1969). Crystalline lysine decarboxylase. Biochem Biophys Res Commun 34, 34-39.
Waterman, S. R. \& Small, P. L. C. (1996). Identification of $\sigma^{\text {s. }}$ dependent genes associated with the stationary-phase acidresistance phenotype of Shigella flexneri. Mol Microbiol 21, 925-940.

Zoon, P. \& Allersma, D. (1996). Eye and crack formation in cheese by carbon dioxide from decarboxylation of glutamic acid. Neth Milk Dairy J 50, 309-318.

Received 25 November 1998; revised 9 February 1999; accepted 25 February 1999. 